\title{
Non-discrimination in Education: Definitions, Principles and Legal Framework
}

\author{
Ina Karakulka ${ }^{1}$ and Anastasiya Zhurko ${ }^{2}$ \\ ${ }^{1} \mathrm{PhD} /$ Assoc. Prof, dean of the Specialists' Additional Education Faculty of the Institute of advanced training and \\ retraining of the Belarusian State Pedagogical University named after Maxim Tank, Minsk, Belarus \\ ${ }^{2}$ Master of Science (MSc) degree in Pedagogical Sciences, independent researcher, Belarus
}

\begin{abstract}
The rights of educational workers are a firm Foundation to implement the quality of professional work and further professional development and self-development. The article outlines the types of discrimination in education. Knowledge of the rights and ability to use them will help teachers to protect themselves in taking place cases of discrimination against them
\end{abstract}

Keywords: Education, legal framework, discrimination in education, equality and justice in images

\section{Introduction}

The priority direction of the State is to ensure the most important human rights including the right to education.

The Universal Declaration of Human Rights of December 10, 1948, in Article 26, proclaims the principle of non-discrimination and the right of every person to education: "education must be directed towards the full development of the human person and towards increasing respect for human rights and fundamental freedoms".

The United Nations Convention against Discrimination in Education (adopted on 14.12.1960), in article 1 defined discrimination: "discrimination" is "any distinction, exclusion, restriction or preference based on race, colour, sex, language, religion, political or other opinion, national or social origin, economic situation or birth which has the purpose or effect of destroying or disrupting the equality of relations in the field of education, and in particular: closing for any person or group of persons up to the formation of any stage or type; restriction of education for a person or a group of people with a lower level of education; the creation or preservation of separate educational systems or educational institutions for any person or group of persons ... or a position incompatible with the dignity of the person to which any person or group of Persons is put. "

The principle of non-discrimination is one of the main principles that underlies the state right to grant to its citizens and other subjects of national law from another state general conditions equal to those granted by that other state in relation to all other states. This right does not apply to the provision of eligible, special, preferential, more favourable conditions; this is the difference between the content of the principle of non-discrimination and the principle of the most favoured nation. The principle of non-discrimination means the obligation not to worsen for other countries its conditions for all countries, and the most-favoured-nation treatment obliges the partner country to grant preferential terms that are or can be introduced for third countries. According to the principle of non-discrimination, the state is obliged not to allow any differences that would create conditions for some other states, as well as for their people and organizations, which are worse than those, common to all other states. 
Ensuring non-discrimination is the basis for building inclusive societies that have overcome differences based on gender, race, ethnicity, religion, language, citizenship.

\section{Definitions and scope}

In this Convention, the word "education" refers to all types and levels of education and includes access to education, the level and quality of education, as well as the conditions in which it is provided.

The scope of "access to education" concept is determined on the basis of a systemic interpretation of the 1960 Convention as a whole. So, in the first part of Art. 3 the goal that should be achieved by fulfilling the obligation of equal access is formulated: the elimination and prevention of discrimination in education. Paragraph 1 of Art. 1 of the 1960 Convention extends the concept of discrimination in the widest possible way and "covers every distinction, exclusion, restriction or preference on the basis of race, colour, sex, language, religion, political or other opinion, national or social origin, economic situation or birth, which has the purpose or effect of destroying or disrupting the equality of relations in the field of education". It is also interesting to see the content of paragraph 2 of Art. 1 of this Convention: "the word "education" refers to all types and levels of education and includes access to education, the level and quality of education, as well as the conditions in which it is conducted." In addition, item b of Art. 3 provides for the obligation of States to take measures, including legislative measures, aimed at eliminating all discrimination when enrolling in educational institutions.

1. The wording "the same ... as for its citizens" indicates the obligation to grant a national treatment to foreign citizens and stateless persons.

2. In Article 2 of the Convention the following provisions are not considered discrimination:

3. a) the creation or preservation of separate educational systems or educational institutions for students of different sex in those cases where these systems or institutions provide equal access to education when their teaching staff have equal qualifications, when they have premises and equipment of equal quality and allow for training for the same programs;

4. b) the creation and preservation, on motives of a religious or linguistic nature, of various educational systems or educational institutions that are appropriate for the choice of parents or legal guardians of students, in cases where the inclusion in these systems or income to these institutions is voluntary and if the education they give corresponds to the norms, prescribed or approved by the competent educational authorities, in particular with respect to the formation of the same level;

5. c) the creation or preservation of private educational institutions in cases where their purpose is not to exclude a group of the population but only to supplement the educational opportunities provided by the state, provided that their activities meet the above-mentioned purpose and that the education they give corresponds to the norms, prescribed or approved by the competent ornaments of education, particularly in regard to the norms of education of the same level [1, p. 713-714].

Consider the grounds that can be defined in educational practice as discriminatory. General approaches to discrimination and its prevention in the field of education were elaborated by the General Conference of the United Nations Educational, Scientific and Cultural Organization and were reflected in the Convention against Discrimination. Discrimination was declared a type of violation of the rights of children and, therefore, an object of the struggle of the world community. Priorities in education were declared inadmissibility of discrimination and the proclamation of the right of every person to education and equal access to it. It was noted that, based on the diversity of education systems adopted in individual countries, they should not only eliminate all discrimination in education, but also promote universal equality of opportunity in this field. The modern case law of individual states in the field of preventing discrimination in education is based on the above-mentioned Convention.

This Convention has become the basis for the implementation of the practice of anti-discrimination legislation in the national legislation of many European countries. 


\subsection{Discrimination in the workplace}

Discrimination in the workplace means different and less favourable treatment of people due to their characteristics that are not relevant to their merit or the requirements for this work (race, colour, religion, gender, etc.). The following types of labour discrimination in the field of education are distinguished:

- discrimination in salary of some workers or groups of workers compared to others.

- discrimination in hiring, dismissal from work. Such discrimination in education is usually applies to people released from prisons, prisoners, disabled people, unskilled young people. Unequal opportunities for employment can arise because of the age of the employee, race and ethnicity.

- occupational segregation, manifested in a sustained separation of professions and positions between different groups of workers. For example, there are traditional male and female professions, including education, which in the countries of Eastern Europe refers to the predominantly female profession.

Other forms of discrimination include age, disability (disability), and sexual orientation.

\subsection{Gender discrimination}

Gender discrimination is common, although it is difficult to detect and more or less veiled. Many public institutions and media preserve and disseminate stereotypes about men and women. Traditional gender traits in society are often associated with power: men and their usual occupations are characterized as strong, productive, brave, important, socially oriented, influential and receiving high financial rewards and social recognition and value. The key characteristics of women reflect impotence: dependent, caring, passive and family oriented. Women often hold subordinate positions; their work is valued less and receives less recognition and reward.

Examples of inequality in relation to women are lower incomes, insufficient representation at the highest levels of the career ladder and concentration in less prestigious and less profitable economy sectors. Women of childbearing age are particularly vulnerable. At the same time, gender imbalance in the labour market is largely reproduced through the educational system. Common stereotypes concerning the roles and responsibilities of women and men in the family and society have a negative impact on the social status of women and prevent their equal participation in political and economic life. The authorities recognized problems of gender inequality in Belarus, which became the basis for taking concrete measures to overcome it.

\subsection{Discrimination based on confession}

Freedom of religion is officially observed in many countries, however, discrimination based on confession is widespread, and often it is inseparably linked with racism and xenophobia. For example, in the past, Europe was torn apart by the conflicts and discrimination of Protestants and Catholics, Catholics and Orthodox, as well as "official" churches and schismatic denominations, today these differences among Christians have become much less significant. At the same time, many minority religious communities continue to flourish in Europe, including Jews, Hindus, Buddhists, Baha'is, Rastafarian and Muslims. This growing religious diversity is often ignored, as millions of Europeans are - atheists and non-Christians. Of particular concern is the growing Islamophobia - discrimination, fear and hatred of Islam, which is the most widespread religion in Europe after Christianity and the predominant religion in some countries and regions in the Balkans and the Caucasus. Hostility towards Islam after the attack on objects in the US, Spain and England in recent years has revealed deep-rooted prejudices in most European societies. Some of the most typical public expressions of this prejudice are the inadequate official recognition of Islam as a religion, the denial of permission to build mosques, the lack of support for Muslim religious groups or communities and the prohibitions against women and girls wearing hijab. 
One of the most typical prejudices against Islam is its so-called "incompatibility" with human rights. Confirmation is the lack of democracy and widespread human rights violations in many predominantly Muslim countries, without recognizing the fact that religion is one of many factors that can contribute to the emergence of undemocratic governments.

A lot of prejudices also arise from the lack of knowledge about Islam, which many people associate only with terrorism and extremism and with the policies of certain countries. In fact, Islam, like most religions, preaches tolerance, solidarity and love for one's neighbour.

The Belarusian authorities differentiate between the five "traditional" religions, led by Orthodoxy, and other denominations, both in legislation and in administrative practice. However, restrictive regulation confronts all confessions without exception. Nevertheless, state policy is aimed at preventing the spread of "new religious movements", often for reasons of state security and protecting the "traditional" identity of Belarusians. In addition to legal, the existing administrative barriers should also be taken into account. At the same time, the vulnerability of religious groups depends to a large extent on their social activity and their connections with the political opposition. A special problem is still the unresolved issue of the passage of an alternative service. Thus, discrimination on religious grounds, especially members of groups not belonging to "traditional" denominations, is possible in Belarus and at the level of legislation and practice. At the same time, the severity of problems is largely reduced by the low level of "active religiosity" of the majority of the Belarusian population.

\subsection{Discrimination related to sexual orientation}

Homophobia is an aversion or hatred towards gays, lesbians or homosexuals or their way of life or culture, or, in general, to people with a different sexual orientation, including bisexual and transgender people. Although legislative reforms in Europe have significantly strengthened the rights of gay and lesbian people, the conditions vary considerably in urban areas where homosexuals openly live, work and can almost easily create civil unions, and in rural areas and regions of Eastern and Central Europe where gays can face discriminatory laws, harassment and even violence by the public and authorities. Some people still consider homosexuality a disease, a psychological disorder or even a sin. Others, consciously or unconsciously, apply heterosexual norms to gays and lesbians, accusing them of inconsistency with the types of behavior expected of "normal people".

Representatives of a very much closed Lesbian, Gay, Bisexual and Transgender (LGBT) community are faced with inequality and discrimination in various spheres of public life in Belarus. They are often victims of physical and psychological violence. Discrimination of members of the LGBT community can take place in the labor market, in trade and in the provision of services, in the realization of the right to freedom of assembly and association. The general principles of equality and non-discrimination in Belarusian law may be ineffective to protect members of this community because of the general atmosphere of intolerance towards them in Belarusian society.

\subsection{Discrimination related to disabilities}

The term "person with disabilities" can describe a wide variety of conditions: limited opportunities, which can be physical, intellectual, sensory or psychosocial, temporary or permanent and can be a result of illness, injury or heredity. People with disabilities have the same human rights as all other people. However, for a number of reasons, they often face social, legal and practical barriers when they demand respect for their rights on an equal basis with others. The reason for this is incorrect perception and negative attitudes toward the very limited possibilities themselves.

Many people have a wrong idea that people with disabilities cannot be productive members of society. The main negative attitude is that people with disabilities are "sick" or have "frustrated health" and that they need treatment or healing, or that they are helpless and they need care. 


\section{Conclusion}

Discrimination has a negative impact on the socio-psychological climate of the school. Because of discrimination it is impossible to take place, and children are deprived of the opportunity to exercise their right to education fully. Labour, gender, religious and other stereotypes against teachers, children are often the cause of their discrimination at school. Actual or perceived sexual orientation, features in mental and / or physical development within the framework of many cases of discrimination. School management, teachers, parents do not always know how to prevent discrimination, to react to its cases.

The knowledge of their rights and the ability to use them will help pedagogical workers to protect themselves in the cases of their discrimination.

\section{Acknowledgements}

This research was partially supported by Institute of advanced training and retraining of the Belarusian State Pedagogical University named after Maxim Tank (hereinafter-BSPU), Francisk Skorina Gomel State University (hereinafter-GSU). We are thankful to our colleagues Veronica Radygina from BSPU, Alexander Grahotsky from GSU who provided expertise that greatly assisted the research, although they may not agree with all of the interpretations provided in this paper.

\section{References}

[1] Convention against Discrimination in Education / UN. [Online]. Available: http://www.un.org/en/documents/decl conv/conventions/educat.shtml

[2] General Comment No. 13 (Twenty-first session, 1999): The right to education (art. 13) / Human Rights Library [Online]. Available: http://hrlibrary.ngo.ru/russian/gencomm/Rescgencom13.html

[3] Implementation of the Convention and Recommendation against Discrimination in the Region: Results of the Eighth Consultation with Member States (2011-2013): UNESCO: Paris, 2013. [Online]. Available: http://unesdoc.unesco.org/images/0022/002221/222100r.pdf

[4] The Universal Declaration of Human Rights. [Online]. Available: http://www.un.org/en/documents/decl_conv/declarations/declhr.shtml

[5] Vienna Declaration and Program of Action: adopted by the World Conference on Human Rights on 25 June 1993 in Vienna. [Online]. Available: http://un.by/documents/humrights/viennaprog 